\title{
Distribution of CYP2C9 and VKORC1 Gene Polymorphisms in Healthy Macedonian Male Population
}

Krume Jakjovski ${ }^{1}$, Nikola Labachevski ${ }^{1}$, Aleksandar Petlichkovski ${ }^{2}$, Aleksandar Senev ${ }^{2}$, Jasmina Trojacanec ${ }^{1}$, Emilija Atanasovska ${ }^{1}$, Elena Kostova ${ }^{1}$, Mirko Spiroski ${ }^{2}$

${ }^{1}$ Institute of Preclinical and Clinical Pharmacology with Toxicology, Faculty of Medicine, Ss Cyril and Methodius University of Skopje, Republic of Macedonia; ${ }^{2}$ Institute of Immunobiology and Human Genetics, Faculty of Medicine, Ss Cyril and Methodius University of Skopje, Republic of Macedonia

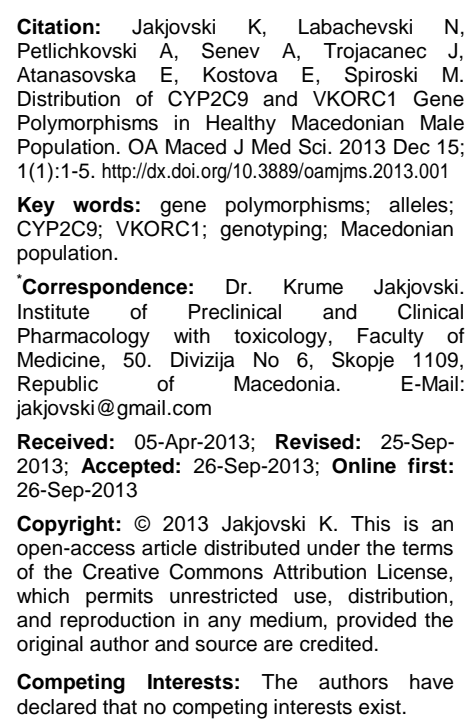

Copyright: () 2013 Jakjovski K. This is an open-access article distributed under the terms of the Creative Commons Attribution License, which permits unrestricted use, distribution, and reproduction in any medium, provided the original author and source are credited.

Competing Interests: The authors have declared that no competing interests exist.

\begin{abstract}
Background: Distribution of CYP2C9 and VKORC1 gene polymorphisms may vary significantly among different ethnic groups, and eventually influence the variation in drug metabolism or even failure.

Objective: The aim of this study was to evaluate the prevalence of CYP2C9 and VKORC1 alleles in the healthy population of Republic of Macedonia compared to the global geographic data reported from different ethnic populations. Also, to genotype CYP2C9 and VKORC1 genes and eventually to divide individuals in poor, extensive, or intermediate metabolizer.

Material and Methods: Blood samples were collected after signing written consent, DNA was isolated from peripheral blood, and CYP2C9 and VKORC1 genes were typed $(n=124)$. Genotyping was performed by commercially available kits (GenelD GmbH, Strassberg, Germany, AID Diagnostica), based on the method of polymerase chain reaction with a subsequent hybridization. The population genetics analysis package, PyPop ver. 0.6.0, was used for analysis of the data.

Results: The frequency of alleles varies from 0.931 for CYP2C9*3 to 0.109 for CYP2C9*2 indicating common "wild type" allele in those genes. The frequency ranges spanned $\sim 50 \%$ for each allele of VKORC1 gene, indicating no common "wild type" allele in this gene. Test of neutrality showed significant negative value for VKORC1 polymorphism that indicates balancing selection operating on the alleles at that locus. All polymorphisms of CYP2C9*2, CYP2C9*3 and VKORC1 showed a good fit with Hardy-Weinberg expectations.
\end{abstract}

Conclusion: The results of polymorphic alleles of CYP2C9 and VKORC1 genes in Macedonian population can be used for the variation in drug metabolism studies as well for adapting dosage regimes for oral anticoagulant therapies.

\section{Introduction}

The cytochrom P450 (CYP) family of heme monooxygenases comprise the most important group of Phase I enzymes. These enzymes oxidize a wide range of endogenous, as well as exogenous compounds. The cytochrome $\mathrm{P} 450$ gene family contains 60-100 different genes, of which only a small group is involved in drug and chemical transformations. The most important P450 isoenzyme is CYP3A4 (50\% of the P450 metabolism) followed by CYP2D6 (20\%), CYP2C9 and CYP2C19 (together $15 \%)$. The remaining is carried out by CYP2E1, CYP2A6 and CYP1A2 [1]

The genes for CYP2D6, CYP2C9, CYP2C19 and CYP2A6 are functionally polymorphic. Therefore, approximately $40 \%$ of human P450 dependent drug metabolism is carried out by polymorphic enzymes (for a list of all currently known cytochrome P450 gene alleles go to http://www.cypalleles.ki.se/ ) [2].

There are 3 CYP2C9 alleles - CYP2C9*1 allele is wild-type, but $C Y P 2 C 9^{*} 2$ and $C Y P 2 C 9 * 3$ are mutated alleles. In both mutated alleles, a point mutation leads to a substitution of an amino acid in the protein. In CYP2C9*2 an arginine at position 144 is converted to cystein (R144C), in CYP2C9*3 an isoleucine at position 359 is converted to leucine (I359) Cytochrom P450 CYP2C9 catalyse the metabolism of important drugs such as phenytoin, tolbutamide, losartan, warfarin, and several NSAILs [3]. Interestingly, significant variation in distribution of polymorphic variants of the CYP450 genes is 
documented among different populations worldwide [4-25]. The vitamin $\mathrm{K}$ epoxide reductase (VKOR) is a membrane protein in the endoplasmic reticulum, which catalyses the transformation of vitamin $\mathrm{K} 2,3$ epoxide into vitamin $\mathrm{K}$ hydroxyquinone, which is essential for the synthesis of factors II, VII, IX and XI of the coagulation system, as well as proteins $C$ and $\mathrm{S}$. The enzyme vitamin $\mathrm{K}$ epoxide reductase is pharmacodynamic target of oral anticoagulants and is encoded by the VKORC1 gene.

Macedonia is located in the Central Balkans, bordering Bulgaria, Greece, Albania, Serbia and Kosovo province, covering an area of $25,710 \mathrm{kms}$. According to the 2002 census, the country's population was 2,022,577. Data on the declared ethnic affiliation from the 2002 census reported that $64.1 \%$ of the population identify themselves as Macedonian, $25.17 \%$ as Albanian, 3.95\% as Turks, $2.66 \%$ as Roma, $1.78 \%$ as Serbs, $0.84 \%$ as Bosniacs, $0.48 \%$ as Vlachs and $1.04 \%$ others [26]. The country seceded peacefully from Yugoslavia after an independence referendum, held in September 1991.

This is the first study of the diversity of polymorphisms of $\mathrm{CYP}_{2 C 9^{*} 2,} \mathrm{CYP} 2 \mathrm{C9}{ }^{*} 3$ and $V K O R C 1$ in Macedonian populations. The aim of this study was to determine the frequencies of $C Y P 2 C 9^{*} 2$, CYP2C9*3 and VKORC1 alleles and genotypes and to compare them with populations for which similar data are available.

\section{Material and Methods}

\section{Population}

Unrelated healthy male volunteers of Macedonian origin $(n=124)$, between the age of $18-55$ years with a mean age of $36.43( \pm 3.47)$ years, which are subjects of bioequivalnece studies, were included in the study. All individuals are of Macedonian origin, nationality, and residents of the geographical areas of different regions of the Republic of Macedonia. From each individual was obtained signed informed consent prior to his or her enrolment. The Ethical Committee of the Faculty of Medicine in Skopje has approved the study. After admission to the study, blood samples were collected from each subject $(5 \mathrm{ml})$ into an EDTA tube, and the genomic DNA was isolated from peripheral blood leukocytes by the phenol-chloroform extraction method [27]. Samples were stored in Anthropology field of the Macedonian Human DNA Bank (hDNAMKD) [28].

\section{Typing methods}

CYP2C9*2 (rs1799853), CYP2C9*3 (rs1057910), and VKORC1 C1173T (rs 9934438) polymorphysims genotyping was performed by commercially available kits from GenelD $\mathrm{GmbH}$, Strassberg, Germany. It is based on the method of polymerase chain reaction (PCR) with a subsequent hybridization. A multiplex PCR is first carried out with DNA isolated from whole blood. In this reaction, two fragments of the CYP2C9 gene and one fragment of the $V K O R C 1$ gene are amplified with specific biotin labelled primers. The amplified gene fragments are then characterized in a hybridization reaction with sequence-specific oligonucleotide probes (SSOP), which are immobilized on nitrocellulose (reverse hybridization). Each nitrocellulose strip has gene probes for the wild-type and mutated sequences of the tested gene fragments, as well as control zones.

\section{Statistical methods}

The population genetics analytics package, PyPop ver. 0.6.0 [29], was used for analysis of the gene data. Allele frequencies and expected Hardy Weinberg proportions (HWP) [30] for each single nucleotide polymorphisims (SNP) were determined. The exact test for genotype frequency deviation from HWP was calculated using the Arlequin implementation accessed via PyPop. Those SNPs that did not fit HWP were evaluated to determine wheather there was an excess of homozygotes or heterozygotes, or if any particular genotypes were significantly different fom expected frequencies by the Chi-square test. The Ewens-Watterson homozygozity test of neutrality with Slatkin's p-values [31] was used to indicate any deviations from the hypothesis of neutral selection for each locus. P-value less than 0.05 was taken as significant.

\section{Results}

\section{CYP2C9 and VKORC1 Alleles}

Frequencies of polymorphic alleles, test of neutrality with $F_{\text {nd }}$ statistic [Ewens-Watterson test of neutrality $(E W N)]$, and Slatkin's Exact $p$-value (SEPV) with $p$ of $F$ statistics in macedonian population are shown on the Table 1. The frequency of alleles varies from 0.931 for $C Y P 2 C 9{ }^{*} 3$ to 0.109 for $C Y P 2 C 9{ }^{*}$, indicating common "wild-type" allele in these genes. The frequency ranges spanned $\sim 50 \%$ for each allele of VKORC1 gene, indicating no common "wild type" allele in this gene (Table 1 ).

Table 1: Frequencies of polymoprhic alleles, test of neutrality with $F_{\text {nd }}$ statistic (Ewens-Watterson test of neutrality (EWN)), and Slatkin's Exact $P$. Value (SEPV) with $p$ of $F$ statistics in Macedonian population.

\begin{tabular}{|c|c|c|c|c|c|}
\hline \multirow{3}{*}{ Polymorphism } & \multirow{2}{*}{\multicolumn{3}{|c|}{ Alleles }} & \multicolumn{2}{|c|}{ Test of neutrality } \\
\hline & & & & \multirow{2}{*}{$\begin{array}{c}\text { EWN } \\
F_{n d}\end{array}$} & \multirow{2}{*}{$\begin{array}{l}\text { SEPV } \\
p \text { of } F\end{array}$} \\
\hline & Allele & Number & Frequency & & \\
\hline \multirow{2}{*}{ CYP2C9*2 } & ${ }^{*} 1$ & 221 & 0.891 & \multirow{2}{*}{-0.186} & \multirow{2}{*}{0.346} \\
\hline & *2 & 27 & 0.109 & & \\
\hline \multirow{2}{*}{ CYP2C9*3 } & ${ }^{* 1}$ & 231 & 0.931 & \multirow{2}{*}{0.210} & \multirow{2}{*}{0.430} \\
\hline & *3 & 17 & 0.069 & & \\
\hline VKORC1 & C & 134 & 0.540 & -1.995 & $0.027^{*}$ \\
\hline
\end{tabular}

directional selection; ${ }^{*}$ statistically significant. 
Test of neutrality showed negative values for $F_{\text {nd }}$ statistics (Ewens-Watterson test of neutrality) for CYP2C9*2 and VKORC1 polymorphism (-0.186 and 1.995, respectively), which indicates balancing selection operating on the alleles at that locus, but significantly different from 0 only for the VKORC1 gene [Slatkin's exact $P$ value (SEPV) 0.346 and 0.027 , respectively]. $F_{n d}$ was positive and none significantly differs from 0 for CYP2C9 ${ }^{*} 3\left(F_{n d}=0.210\right.$ and $p$ of $F=0.430$ ) (Table 1).

\section{CYP2C9 and VKORC1 genotypes}

Twenty-three individuals (18.6\%) were heterozygous for $C Y P 2 C 9^{*} 2$, whereas 17 individuals $(13.7 \%)$ were heterozygous for CYP2C9*3. There were two individuals (1.6\%) which are homozygous for CYP2C9*2, but no individual was homozygous for CYP2C9*3. In addition, there were no individuals declared as heterozygotes $\left({ }^{*} 2 /{ }^{*} 3\right)$. Thus, only 2 individuals can be predicted as subjects to have the lowest CYP2C9 enzymatic activity, with respect to *2 and ${ }^{*} 3$; so they may be declared as PM (poor metabolizers).

Table 2: Observed vs expected CYP2C9*2, CYP2C9*3 and VKORC1 genotypes, Hardy Weinberg proportions (HWP), and Guo Thompson Hardy Weinberg Output (GTHWO) in macedonian population.

\begin{tabular}{|c|c|c|c|c|c|c|c|}
\hline $\begin{array}{l}\text { Polymor- } \\
\text { phism }\end{array}$ & $\begin{array}{l}\text { Geno- } \\
\text { type }\end{array}$ & $\begin{array}{c}\text { Obser- } \\
\text { ved } \\
\text { number } \\
\text { (n) }\end{array}$ & $\begin{array}{c}\text { Obser- } \\
\text { ved } \\
\text { freq- } \\
\text { uency } \\
(\%)\end{array}$ & $\begin{array}{c}\text { Expec- } \\
\text { ted } \\
\text { number } \\
(\%)\end{array}$ & $\begin{array}{c}\mathrm{p}- \\
\text { value }\end{array}$ & $\begin{array}{c}\text { HWP } \\
\text { p- } \\
\text { value }\end{array}$ & $\begin{array}{l}\text { GTHWO } \\
\text { p-value }\end{array}$ \\
\hline \multirow{3}{*}{ CYP2C9*2 } & $* 1 / * 1$ & 99 & 79.8 & 98.5 & 0.829 & \multirow[b]{2}{*}{0.824} & \multirow[b]{2}{*}{0.634} \\
\hline & $\begin{array}{l}{ }^{*} 1 / * 2 \\
* 2 / * 2\end{array}$ & $\begin{array}{c}23 \\
2\end{array}$ & $\begin{array}{c}18.6 \\
1.6\end{array}$ & $\begin{array}{c}24.1 \\
1.5\end{array}$ & $\begin{array}{c}0.957 \\
\&\end{array}$ & & \\
\hline & ${ }^{*} 1 /{ }^{* 1}$ & 107 & 86.3 & 107.6 & 0.995 & \multirow{3}{*}{0.765} & \multirow{3}{*}{1.00} \\
\hline \multirow[t]{3}{*}{ CYP2C9*3 } & $* 1 / * 3$ & 17 & 13.7 & 15.8 & 0.769 & & \\
\hline & ${ }^{*} 3 /{ }^{*} 3$ & 0 & 0 & 0.6 & $\&$ & & \\
\hline & $C / C$ & 37 & 29.8 & 36.2 & 0.894 & \multirow{3}{*}{0.772} & \multirow{3}{*}{0.858} \\
\hline \multirow{2}{*}{ VKORC1 } & $C / T$ & 60 & 48.4 & 61.6 & 0.838 & & \\
\hline & $T / T$ & 27 & 21.8 & 26.2 & 0.876 & & \\
\hline
\end{tabular}

Overall, the CYP2C9*2 allele had a frequency of $10.1 \%$, whereas the CYP2C9*3 allele had a frequency of $6.8 \%$. The observed genotype frequencies for both polymorphisms for CYP2C9 were consistent with Hardy Weinberg equilibrium (Table 2).

Sixty individuals $(48.4 \%)$ were heterozygous for VKORC1 polymorphism, whereas 27 individuals $(21.8 \%)$ had a homozygous genotype. The observed genotype frequencies for VKORC1 were consistent with Hardy Weinberg equilibrium (Table 2).

Observed versus expected genotypes for each SNP, Hardy-Weinberg proportion (HWP), and Guo and Thomson Hardy Weinberg Output (GTHWO) is given in the Table 3. All polymorphisms of CYP2C9*2, CYP2C9*3 and VKORC1 showed a good fit with HWP expectations (HWP p-value $=0.824,0.765$ and 0.772 , respectively). In two instances, $x^{2}$ test cannnot be calculated because expected frequency was smaller than $5\left(\right.$ CYP $2 C 9^{*} 2{ }^{*} 2{ }^{*} 2$ and $\mathrm{CYP}^{2}{ }^{*}{ }^{*} 3$ $\left.{ }^{*} 3 /{ }^{*} 3\right)$.
Table 3: Comparison of CYP2C9 allelic frequencies reported from different ethnic groups and different geographic regions.

\begin{tabular}{|c|c|c|c|c|c|}
\hline Population & $\mathrm{n}$ & \multicolumn{3}{|c|}{$\begin{array}{c}\text { CYP2C9 variant allele } \\
\text { Frequency, (p-value; NS-non significant) }\end{array}$} & $\begin{array}{l}\text { Refe- } \\
\text { rence }\end{array}$ \\
\hline \multicolumn{6}{|l|}{ Caucasians } \\
\hline $\begin{array}{l}\text { Republic of } \\
\text { Macedonia }\end{array}$ & 124 & $\begin{array}{c}0.831 \\
\text { (referent) }\end{array}$ & $\begin{array}{c}0.101 \\
\text { (referent) }\end{array}$ & $\begin{array}{c}0.068 \\
\text { (referent) }\end{array}$ & $\begin{array}{l}\text { This } \\
\text { study }\end{array}$ \\
\hline Spain & 157 & 0.70 (NS) & $0.14(\mathrm{NS})$ & $0.16(0.001)$ & [4] \\
\hline Italy & 360 & $0.77(\mathrm{NS})$ & 0.12 (NS) & 0.09 (NS) & [5] \\
\hline Slovenia & 129 & 0.82 (NS) & 0.12 (NS) & 0.06 (NS) & [6] \\
\hline Croatia & 200 & $0.74(\mathrm{NS})$ & 0.16 (NS) & 0.09 (NS) & {$[7]$} \\
\hline Greece & 283 & 0.79 (NS) & 0.13 (NS) & 0.08 (NS) & [8] \\
\hline France & 151 & $0.77(\mathrm{NS})$ & 0.15 (NS) & 0.08 (NS) & [9] \\
\hline Germany & 266 & 0.81 (NS) & 0.11 (NS) & 0.08 (NS) & [10] \\
\hline Belgium & 121 & 0.82 (NS) & 0.10 (NS) & 0.07 (NS) & [11] \\
\hline Sweden & 430 & 0.82 (NS) & 0.17 (NS) & 0.07 (NS) & [12] \\
\hline Danmark & 276 & 0.83 (NS) & 0.12 (NS) & 0.05 (NS) & [13] \\
\hline Britain & 100 & 0.84 (NS) & 0.13 (NS) & 0.08 (NS) & {$[14]$} \\
\hline Russia & 290 & 0.83 (NS) & 0.10 (NS) & 0.07 (NS) & [15] \\
\hline Hungary & 332 & 0.86 (NS) & 0.11 (NS) & 0.09 (NS) & [16] \\
\hline America & 100 & 0.85 (NS) & 0.08 (NS) & 0.06 (NS) & [17] \\
\hline Canada & 114 & 0.81 (NS) & $0.03(0.007)$ & 0.06 (NS) & [18] \\
\hline Turkey & 499 & 0.79 (NS) & 0.11 (NS) & 0.10 (NS) & [10] \\
\hline \multicolumn{6}{|l|}{ Hispanic } \\
\hline $\begin{array}{l}\text { Mexican } \\
\text { America }\end{array}$ & 169 & $0.86(\mathrm{NS})$ & $0.08(0.029)$ & 0.06 (NS) & [19] \\
\hline Brazil & 331 & $0.86(\mathrm{NS})$ & $0.07(0.017)$ & 0.07 (NS) & [20] \\
\hline \multicolumn{6}{|l|}{ African } \\
\hline Africa & 993 & 0.99 (NS) & $0.02(0.001)$ & $0.01(0.025)$ & [21] \\
\hline $\begin{array}{l}\text { African } \\
\text { America }\end{array}$ & 100 & $0.98(N S)$ & $0.01\left(1 * 10^{-7}\right)$ & $0.005(0.0002)$ & {$[17]$} \\
\hline Egypt & 247 & $0.82(\mathrm{NS})$ & $0.12(\mathrm{NS})$ & $0.06(\mathrm{NS})$ & [22] \\
\hline \multicolumn{6}{|l|}{ Asian } \\
\hline Vietnam & 157 & 0.98 (NS) & $0(<0.0001)$ & $0.02(0.0017)$ & [23] \\
\hline Japan & 218 & $0.98(0.037)$ & $0(<0.0001)$ & $0.021(0.0008)$ & [24] \\
\hline Korea & 574 & $0.99(0.011)$ & $0(<0.0001)$ & $0.011(<0.0001)$ & [24] \\
\hline China & 98 & $0.97(\mathrm{NS})$ & $0(<0.0001)$ & $0.026(0.031)$ & [24] \\
\hline South India & 346 & $0.88(\mathrm{NS})$ & $0.04\left(3^{*} 10^{-1}\right)$ & 0.08 (NS) & [25] \\
\hline
\end{tabular}

Table 3 shows the distribution of frequencies of the CYP2C9 and VCORC1 variant alleles in the healthy population of Republic of Macedonia compared to data reported from various ethnic groups and global geographic regions.

Allelic frequencies of rs9934438 $(1173 C>T)$ polymorphism in VKORC1 in different countries/ regions are presented in Table 4. The lowest frequency of the VKORC1 CC genotype was reported in Chinese populations $(1 \%, 1.11 \%$ and $2.9 \%$ respectively ) [33, 35, 39]. The highest frequencies for VKORC1 CC genotype were reported in Netherlands, Italy and USA $(37.2 \%, 36.8 \%$, and $36.1 \%$ respectively). The frequency of VKORC1 CC genotype in Macedonians was similar to Caucasians $(29.8 \%)$ (Table 4).

Table 4: Allelic frequencies of rs9934438 (1173C>T) polymorphism in VKORC1 in different countries/regions.

\begin{tabular}{|c|c|c|c|c|c|c|}
\hline \multirow{2}{*}{$\begin{array}{c}\text { Reference SNP } \\
\text { rs9934438 } \\
(1173 \mathrm{C}>\mathrm{T})\end{array}$} & \multicolumn{3}{|c|}{ Genotypes } & \multirow[t]{2}{*}{ Country/region } & \multicolumn{2}{|r|}{ Reference } \\
\hline & $\begin{array}{l}\mathrm{CC} \\
(\%)\end{array}$ & $\begin{array}{c}\mathrm{CT} \\
(\%)\end{array}$ & $\begin{array}{c}\mathrm{TT} \\
(\%)\end{array}$ & & & \\
\hline & 29.8 & 48.4 & 21.8 & $\begin{array}{l}\text { Republic } \\
\text { Macedonia }\end{array}$ & of & $\begin{array}{l}\text { This } \\
\text { paper }\end{array}$ \\
\hline & $\begin{array}{c}36.8 \\
36.1 \\
34 \\
1\end{array}$ & $\begin{array}{c}46.9 \\
50.7 \\
49 \\
14\end{array}$ & $\begin{array}{c}16.3 \\
12.7 \\
17 \\
85\end{array}$ & $\begin{array}{l}\text { Italy } \\
\text { USA } \\
\text { France } \\
\text { China }\end{array}$ & & $\begin{array}{l}{[34]} \\
{[32]} \\
{[41]} \\
{[35]}\end{array}$ \\
\hline & 1.11 & $\begin{array}{c}14.7 \\
6\end{array}$ & $\begin{array}{c}84.1 \\
3\end{array}$ & China & & [33] \\
\hline & $\begin{array}{c}2.9 \\
6 \\
11 \\
37.2\end{array}$ & $\begin{array}{c}15.7 \\
25 \\
24 \\
48\end{array}$ & $\begin{array}{c}81.4 \\
69 \\
65 \\
14.8\end{array}$ & $\begin{array}{l}\text { China } \\
\text { Hong Kong } \\
\text { Egypt } \\
\text { Netherlands }\end{array}$ & & $\begin{array}{l}{[39]} \\
{[36]} \\
{[37]} \\
{[38]}\end{array}$ \\
\hline
\end{tabular}

Homozygous genotypes for VKORC1 TT were dominant in the yellow populations $(85 \%, 69 \%$ and $65 \%$ in China, Hong Kong and Egypt, respectively). Dominant heterozygous VKORC1 CT genotypes were reported in all Caucasian populations 
(Republic of Macedonia, Italy, USA, France and Netherlands) with frequencies between $46.9 \%$ and 50.7 (Table 4).

\section{Discussion}

In this study we present the distribution of the common alleles of CYP2C9 that has been found to vary across populations and different ethnic groups. The extent of variation is directly related to the genetic distance between populations and the allele being examined [40].

Results which are obtained from our study, showed that the allelic frequencies of CYP2C9*2 (10.1\%) and CYP2C9*3 $(6.8 \%)$ in tested population were similar to the general frequencies reported for the Caucasian population throughout Europe [41].

Compared to the frequency of CYP2C9*3 found in the Spanish ethnic group (16.2\%) [4] a significant interethnic difference was noticed.

The CYP2C9*2 allele is not found in the Asian population, prevalent in approximately $15 \%$ in Caucasians and variable in populations with African ancestry (1-3.6\% African Americans, 4.3\% Ethiopians). CYP2C9*3 is estimated to $0.5-2.3 \%$ in Africans and $1.1-6.8 \%$ in Asians, but it is more common in Caucasians (3.3-17\%) [41-44].

Several meta-analyses were published about the role of VKORC1 polymorphisms and different clinical conditions. To conduct a systemic review and metaanalysis to investigate the relationship between mean daily warfarin dose (MDWD) and VKORC1 single nucleotide polymorphisms (SNPs), a total of 19 studies were included in the meta-analysis. The frequencies of 1173TT and -1639 AA in Asian patients were higher than those in Caucasian and African populations. Sensitive analyses demonstrated that the impacts of gene polymorphism on warfarin dosage requirement were significantly different between Caucasian and Asian population, and the results of meta-analyses were stable and reliable [45]. Navigating the literature to determine how genotype will influence warfarin response in a particular patient is difficult, due to significant variation in patient ethnicity, outcomes investigated, study design, and methodological rigor. A paper was published where comprehensive search strategy was applied and 117 studies included [46]. Primary outcomes were stable dose, time to stable dose and bleeding events. Assessing study quality highlighted significant variability in methodological rigor. Notably, there was significant evidence of selective reporting, of outcomes and analysis approaches [46].

\section{Conclusion}

This study is the firsts on the distribution of the
CYP2C9 and VKORC1 polymorphism in Macedonian population. This study shows that CYP2C9 and VKORC1 are polymorphic in the Macedonian population. Our data show that the distribution of CYP2C9 variant alleles frequencies are similar to the most of those reported for Caucasians of European descendant, but differ from those of North America Caucasians. Results from this study suggest that the genetically determined capacity of CYP2C9 has to be taken into account in process of designing, conducting and evaluation of pharmacokinetics for investigational drugs [44].

\section{References}

1. Goldstein JA. Clinical relevance of genetic polymorphisms in the human CYP2C subfamily. Br J Clin Pharmacol. 2001; 52(4):349-55.

2. Sarah C Sim. The Human Cytochrome P450 (CYP) Allele Nomenclature Database. http://www.cypalleles.ki.se/, Accessed on December 2012.

3. Zhou SF, Liu JP, Chowbay B. Polymorphism of human cytochrome P450 enzymes and its clinical impact. Drug Metab Rev. 2009; 41(2):89-295.

4. García-Martín E, Martínez C, Ladero JM, Gamito FJ, Agúndez JA. High frequency of mutations related to impaired CYP2C9 metabolism in a Caucasian population. Eur J Clin Pharmacol. 2001; 57(1):47-9.

5. Scordo MG, Caputi AP, D'Arrigo C, Fava G, Spina E. Allele and genotype frequencies of CYP2C9, CYP2C19 and CYP2D6 in an Italian population. Pharmacol Res. 2004; 50(2):195-200.

6. Herman D, Dolzan V, Breskvar K. Genetic polymor- phism of cytochromes P450 2C9 and 2C19 in Slovenian population. Zdrav Vestn. 2003; 72, 347-351.

7. Bozina N, Granić P, Lalić Z, Tramisak I, Lovrić M, StavljenićRukavina A. Genetic polymorphisms of cytochromes P450: CYP2C9, CYP2C19, and CYP2D6 in Croatian population. Croat Med J. 2003; 44(4):425-8.

8. Arvanitidis K, Ragia G, Iordanidou M, Kyriaki S, Xanthi A, Tavridou A, Manolopoulos VG. Genetic polymorphisms of drug-metabolizing enzymes CYP2D6, CYP2C9, CYP2C19 and CYP3A5 in the Greek population. Fundam Clin Pharmacol. 2007; 21(4):419-26.

9. Yang JQ, Morin S, Verstuyft C, Fan LA, Zhang Y, Xu CD, Barbu V, Funck-Brentano $C$, Jaillon $P$, Becquemont $L$. Frequency of cytochrome P450 2C9 allelic variants in the Chinese and French populations. Fundam Clin Pharmacol. 2003; 17(3):373-6.

10. Aynacioglu AS, Brockmöller J, Bauer S, Sachse C, Güzelbey $\mathrm{P}$, Ongen Z, Nacak M, Roots I. Frequency of cytochrome P450 CYP2C9 variants in a Turkish population and functional relevance for phenytoin. Br J Clin Pharmacol. 1999; 48(3):40915.

11. Allabi AC, Gala JL, Desager JP, Heusterspreute M, Horsmans Y. Genetic polymorphisms of CYP2C9 and CYP2C19 in the Beninese and Belgian populations. Br J Clin Pharmacol. 2003; 56(6):653-7.

12. Yasar Ü, Eliasson E, Dahl ML, Johansson, IngelmanSundberg M, Sjöqvist F. Validation of methods for CYP2C9 genotyping: Frequencies of mutant alleles in a Swedish population. Biochem Biophys Res Commun. 1999; 254: 628631.

13. Pedersen RS, Verstuyft C, Becquemont L, Jaillon P, Brøsen K. Cytochrome P4502C9 (CYP2C9) genotypes in a Nordic population in Denmark. Basic Clin Pharmacol Toxicol. 2004; $94(3): 151-2$. 
14. Stubbins MJ, Harries LW, Smith G, Tarbit MH, Wolf CR. Genetic analysis of the cytochrome P450 CYP2C9 locus. Pharmacogenetics. 1996; 6: 429-439.

15. Gaikovitch EA, Cascorbi I, Mrozikiewicz PM, Brockmöller J, Frötschl $\mathrm{R}$, Köpke $\mathrm{K}$, et al. Polymorphisms of drugmetabolizing enzymes CYP2C9, CYP2C19, CYP2D6, CYP1A1, NAT2 and of P-glycoprotein in a Russian population. Eur J Clin Pharmacol. 2003; 59(4):303-12.

16. Buzoianu AD, Trifa AP, Mureşanu DF, Crişan $S$. Analysis of CYP2C9*2, CYP2C9*3 and VKORC1 -1639 G>A polymorphisms in a population from South-Eastern Europe. $J$ Cell Mol Med. 2012; 16(12):2919-24.

17. Sullivan-Klose TH, Ghanayem BI, Bell DA, et al. The role of the CYP2C9-leu359 allelic variant in the tolbutamide polymorphism. Pharmacogenetics. 1996; 1996; 6: 341-349.

18. Gaedigk A, Casley WL, Tyndale RF, Sellers EM, JurimaRomet M, Leeder JS. Cytochrome P4502C9 (CYP2C9) allele frequencies in Canadian Native Indian and Inuit populations. Can J Physiol Pharmacol. 2001; 79(10):841-7.

19. Kramer MA, Rettie AE, Rieder MJ, Cabacungan ET, Hines RN. Novel CYP2C9 promoter variants and assessment of their impact on gene expression. Mol Pharmacol. 2008; 73(6):175160.

20. Vianna-Jorge R, Perini JA, Rondinelli E, Suarez-Kurtz G. CYP2C9 genotypes and the pharmacokinetics of tenoxicam in Brazilians. Clin Pharmacol Ther. 2004; 76(1):18-26.

21. Dandara C, Lombard Z, Du Plooy I, McLellan T, Norris SA Ramsay M. Genetic variants in CYP $(-1 \mathrm{~A} 2,-2 \mathrm{C} 9,-2 \mathrm{C} 19,-3 \mathrm{~A} 4$ and -3A5), VKORC1 and ABCB1 genes in a black South African population: a window into diversity. Pharmacogenomics. 2011; 12 (12):1663-70.

22. Hamdy SI, Hiratsuka M, Narahara K, El-Enany M, Moursi N, Ahmed MS, Mizugaki M. Allele and genotype frequencies of polymorphic cytochromes P450 (CYP2C9, CYP2C19, CYP2E1) and dihydropyrimidine dehydrogenase (DPYD) in the Egyptian population. Br J Clin Pharmacol. 2002; 53(6):596603.

23. Lee SS, Kim KM, Thi-Le H, Yea SS, Cha IJ, Shin JG. Genetic polymorphism of CYP2C9 in a Vietnamese Kinh population. Ther Drug Monit. 2005; 27(2):208-10.

24. Bae JW, Kim HK, Kim JH, Yang SI, Kim MJ, Jang CG et al.. Allele and genotype frequencies of CYP2C9 in a Korean population. Br J Clin Pharmacol. 2005; 60(4):418-22.

25. Jose R, Chandrasekaran A, Sam SS, Gerard N, Chanolean S, Abraham BK, Satyanarayanamoorthy K, Peter A, Rajagopal K. CYP2C9 and CYP2C19 genetic polymorphisms: frequencies in the south Indian population. Fundam Clin Pharmacol. 2005;19(1):101-5.

26. State Statistical Office of the Republic of Macedonia. Census 2002: Total population of the Republic of Macedonia according to declared ethnic affiliation. In: Statistical Yearbook of the Republic of Macedonia 2004. Skopje, 2004:61-2.

27. Towner P. Purification of DNA. Essential Molecular Biology T. A. Brown. Oxford, Oxford University Press, 1995:47-54.

28. Spiroski M, Arsov T, Petlichkovski A, Strezova A, Trajkov D, Efinska-Mladenovska O, Zaharieva E. (2005) Case Study: Macedonian Human DNA Bank (hDNAMKD) as a source for public health Genetics. Health Determinants in the Scope of New Public Health. B. G. Georgieva L. Sofia, Hans Jacobs Company, 33-44.

29. Lancaster AK, Single RM, Solberg OD, Nelson MP, Thomson G. PyPop update - a software pipeline for large-scale multilocus population genomics. Tissue Antigens. 2007; 69 (s1): 192-197.

30. Guo SW, Thompson EA. Performing the exact test of HardyWeinberg proportion for multiple alleles. Biometrics. 1992; 48(2): 361-72.

31. Slatkin M. A correction to the exact test based on the Ewens sampling distribution. Genet Res. 1996;68(3):259-60.

32. Carlquist J, Horne B, Mower C, Park J, Huntinghouse J, McKinney J, Muhlestein J, Anderson J. An evaluation of nine genetic variants related to metabolism and mechanism of action of warfarin as applied to stable dose prediction. J Thromb Thrombolysis. 2010;30:358-64.

33. Wang TL, Li HL, Tjong WY, Chen QS, Wu GS, Zhu HT, Hou ZS, Xu S, Ma SJ, Wu M, Tai S. Genetic factors contribute to patient-specific warfarin dose for Han Chinese. Clin Chim Acta. 2008;396:76-9.

34. D'Andrea $G$, D'Ambrosio $R L$, Di Perna $P$, Chetta $M$, Santacroce R, Brancaccio V, Grandone E, Margaglione M. A polymorphism in the VKORC1 gene is associated with an interindividual variability in the dose-anticoagulant effect of warfarin. Blood. 2005;105:645-9.

35. Larramendy-Gozalo C, Yang J, Verstuyft C, Bodin L, Dubert L, Zhang Y, Xu C, Fan L, Jaillon P, Becquemont L. Genetic polymorphism of vitamin $\mathrm{K}$ epoxide reductase (VKORC1) $1173 \mathrm{C}>\mathrm{T}$ in a Chinese and a Caucasian population. Basic Clin Pharmacol Toxicol. 2006;98:611-3.

36. You J, Wong R, Waye M, Mu Y, Lim C, Choi K-c CG. Warfarin dosing algorithm using clinical, demographic and pharmacogenetic data from Chinese patients. J Thromb Thrombolysis. 2011;31:113-8.

37. El Din MS, Amin DG, Ragab SB, Ashour EE, Mohamed MH, Mohamed AM. Frequency of VKORC1 (C1173T) and CYP2C9 genetic polymorphisms in Egyptians and their influence on warfarin maintenance dose: proposal for a new dosing regimen. Int J Lab Hematol. 2012;34(5):517-24.

38. Teichert M, Visser LE, van Schaik RH, Hofman A, Uitterlinden AG, De Smet PA, Witteman JC, Stricker BH. Vitamin K epoxide reductase complex subunit 1 (VKORC1) polymorphism and aortic calcification: the Rotterdam Study. Arterioscler Thromb Vasc Biol. 2008;28(4):771-6.

39. Jiang NX, Song J, Xu B. [Vitamin K epoxide reductase complex 1 gene polymorphism and warfarin dose requirement in Chinese patients]. Zhonghua Xin Xue Guan Bing Za Zhi. 2007;35(7):652-4.

40. Martis S, Peter I, Hulot JS, Kornreich R, Desnick RJ, Scott SA. Multi-ethnic distribution of clinically relevant CYP2C genotypes and haplotypes. Pharmacogenomics J. 2013;13(4):369-77.

41. Sistonen J, Fuselli S, Palo JU, Chauhan N, Padh H, Sajantila A. Pharmacogenetic variation at CYP2C9, CYP2C19, and CYP2D6 at global and microgeographic scale. Pharmacogenet Genomics. 2009; 19(2):170-9.

42. Scordo MG, Aklillu E, Yasar U, Dahl ML, Spina E, IngelmanSundberg M. Genetic polymorphism of cytochrome P450 2C9 in a Caucasian and a black African population. $\mathrm{Br} \mathrm{J}$ Clin Pharmacol. 2001; 52(4):447-50.

43. Mc Graw J, Waller D. Cytochrome P450 variations in different ethnic populations. Expert Opin Drug Metab Toxicol. 2012; 8(3):371-82.

44. Sim SC, Kacevska $M$, Ingelman-Sundberg $M$. Pharmacogenomics of drug-metabolizing enzymes: a recent update on clinical implications and endogenous effects. Pharmacogenomics J. 2013;13(1):1-11.

45. Yang L, Ge W, Yu F, Zhu H. Impact of VKORC1 gene polymorphism on interindividual and interethnic warfarin dosage requirement--a systematic review and meta analysis. Thromb Res. 2010;125(4):e159-66.

46. Jorgensen AL, FitzGerald RJ, Oyee J, Pirmohamed M, Williamson PR. Influence of CYP2C9 and VKORC1 on patient response to warfarin: a systematic review and meta-analysis. PLoS One. 2012;7(8):e44064. 